\title{
The measurement of exchangeable potassium in living pigs and its relation to body composition
}

\author{
By M. F. FULlER, R. A. HOUSEMAN AND A. CADENHEAD \\ Rowett Research Institute, Bucksburn, Aberdeen $A B 2{ }_{9} S B$
}

(Received 23 September 1970-Accepted 12 March 1971)

\begin{abstract}
I. Twenty pigs were reared to a weight of $90 \mathrm{~kg}$ on various dietary regimens so that their lipid content varied from 16 to $38 \%$. They were injected intravenously with $\sim 400 \mu \mathrm{Ci}$ of ${ }^{12} \mathrm{KCl}$. The animals were killed $\sim 28 \mathrm{~h}$ after injection and their contents of water, lipid, sodium and potassium were determined.

2. The specific activity of plasma reached equilibrium $10-12 \mathrm{~h}$ after injection, that of urine not until $20 \mathrm{~h}$ after.

3. Losses of activity in urine, faeces and gut contents in the $24 \mathrm{~h}$ after injection amounted to $3 \cdot 1,0.3$ and $I \cdot 5 \%$ of the injected dose, respectively.

4. Total body $\mathrm{K}$ was more accurately estimated from urine specific activity than from plasma specific activity.

5. Exchangeable $\mathrm{K}$, estimated from urine specific activity $\mathrm{K}_{\mathrm{e}(u)}$, was highly correlated with the weight of fat-free tissue $(r=0.93)$, the residual standard deviation of the regression being $1.8 \mathrm{~kg}$ fat-free tissue.

6. Percentage extractable fat was equally well correlated with $K_{c(u)}(r=-0.92)$.
\end{abstract}

The importance of body composition in animal breeding and husbandry has led to the development of many methods of estimating the composition of living animals. These methods can be divided into two classes: those which attempt to describe the composition of the animal in terms of its tissues (bone, muscle, adipose tissue) and those which aim at a purely chemical description (such as amount of water, protein or lipid). In methods of the latter class, which includes the tracer methods, the body, excluding the gut contents, is considered as consisting of two discrete and chemically unrelated fractions: the fat (lipid) and the fat-free tissue. Irrespective of their relative magnitudes, the composition of each of these fractions is assumed to be, in certain respects at least, constant. It has been known for many years that the concentration of potassium in the fat-free tissue is remarkably invariant over a wide range of circumstances. This knowledge encouraged the development of methods of estimating the $\mathrm{K}$ content of living animals, and thence, by use of a constant factor, the weight of fat-free tissue.

Two methods exist for estimating the $\mathrm{K}$ content of living animals. The first, wholebody counting, makes use of ${ }^{40} \mathrm{~K}$, the natural radioisotope of $\mathrm{K}$, the relative abundance of which is known precisely. This method requires relatively expensive apparatus, and it is difficult to obtain precision with living animals (Kirton \& Pearson, 1963). The second method, based on the dilution in the body $\mathrm{K}$ of an artificial isotope of the element, usually ${ }^{42} \mathrm{~K}$, offers the attractions of simplicity, low capital cost and potentially high accuracy in the living animal. It was first used by Moore (1946) and developed by Corsa, Olney, Steenburg, Ball \& Moore (1950) working with human subjects and rabbits. The latter workers found a high correlation between exchangeable $\mathrm{K}$, 
estimated by isotope dilution, and other indirect estimates of body composition. Later, Talso, Miller, Carballo \& Vasquez (I960) used the ${ }^{42} \mathrm{~K}$ dilution method in both man and rats. The rats were subsequently killed and analysed, when it was found that the exchangeable $\mathrm{K}$, measured by ${ }^{42} \mathrm{~K}$, amounted to $98 \%$ of the total $\mathrm{K}$ determined in the carcasses. The only report of the use of ${ }^{42} \mathrm{~K}$ in pigs is by Pfau (I966), who reported good agreement between values for the fat-free body-weight of four pigs determined by carcass analysis and those estimated by ${ }^{42} \mathrm{~K}$ dilution. However, the factor he used to estimate fat-free weight from exchangeable $\mathrm{K}$ seems to have been derived retrospectively from the carcass analysis of the four pigs.

The object of the experiment to be described here was to make estimates of the exchangeable $\mathrm{K}$ of living pigs differing widely in fatness, and to relate these estimates to various measurements of body composition made by subsequent carcass analysis. Some of these results have already been reported in brief (Fuller, Houseman \& Cadenhead, r970).

\section{EXPERIMENTAL}

\section{Animals and their treatment}

Twenty Large White $\times$ (Large White $\times$ Landrace) castrated male pigs were given one of eight dietary treatments from the time they weighed $20 \mathrm{~kg}$ until they weighed $90 \mathrm{~kg}$. These treatments, which are described in Table I, were combinations of decreasing dietary protein concentration and increasing daily food intake, and were designed to promote large differences in fatness. The average growth rates and percentages of fat in the empty bodies of the pigs on each of these regimens are given in Table 2.

\section{Table I. Composition of the diets and the rates at which they were given to the pigs}

\begin{tabular}{|c|c|c|c|}
\hline Component & $\begin{array}{l}\text { et } \mathrm{I}, 10 \% \\
\text { protein }\end{array}$ & $\begin{array}{l}\text { Diet } 2,14 \% \\
\text { protein }\end{array}$ & $\begin{array}{c}\text { Diet } 3, \text { I } 8 \% \\
\text { protein }\end{array}$ \\
\hline Ground barley (\%) & 92 & 80 & 62 \\
\hline Wheat offal $(\%)$ & 4 & Io & 19 \\
\hline White fish meal (\%) & 2 & 5 & 9 \\
\hline Soya-bean meal $(\%)$ & 2 & 5 & 10 \\
\hline $\begin{array}{l}\text { Added mineral-vitamin mixture } \\
\text { (kg/10o kg main ingredients)* }\end{array}$ & 2 & $\mathbf{I}$ & 0.2 \\
\hline \multirow{3}{*}{$\begin{array}{l}\text { Amount of diet given daily } \\
\left(\mathrm{g} / \mathrm{kg}^{0.73}\right)\end{array}$} & 100 & 90 & 70 \\
\hline & 120 & rro & 80 \\
\hline & I30 & - & 100 \\
\hline
\end{tabular}

* Designed to raise the levels of all required minerals and vitamins to those recommended by the Agricultural Research Council (1967).

The estimates of exchangeable $\mathrm{K}$ were made when the pigs reached approximately $90 \mathrm{~kg}$. At this weight, each pig was put into a galvanized-steel metabolism cage equipped for the collection of urine and faeces. It was given no further food, but water was supplied ad lib. It was anaesthetized with trichloroethylene (Trilene; ICI Ltd) and a fine polyethylene catheter was inserted via an ear vein into the external jugular, by the method of Anderson \& Elsley (1969). On the following day a precisely 
known amount (usually $\sim 0.4 \mathrm{mCi}$ ) of ${ }^{42} \mathrm{~K}$ as $\mathrm{KCl}$ in $\sim 10 \mathrm{ml}$ isotonic saline (PESıP; The Radiochemical Centre, Amersham, Bucks) was injected through the catheter, which was immediately flushed with heparinized saline. The syringe and needle used were weighed immediately before and after the injection, and $\sim 0.2 \mathrm{ml}$ of the same solution as that injected was weighed accurately and diluted for use as the standard for counting. From the time of injection until slaughter, all urine and faeces were collected. The ${ }^{42} \mathrm{~K}$ activity that was lost by these routes was determined by counting samples of each material. From $22 \mathrm{~h}$ after injection until slaughter, each urination was collected separately and blood samples were taken at hourly intervals. These samples were used to estimate the equilibrium specific activity of ${ }^{42} \mathrm{~K}$, as described below.

Table 2. Mean growth rates $(\mathrm{kg} / \mathrm{d})$ of pigs given different rations, and in parentheses, mean percentages of fat in their ingesta-free carcasses

Daily
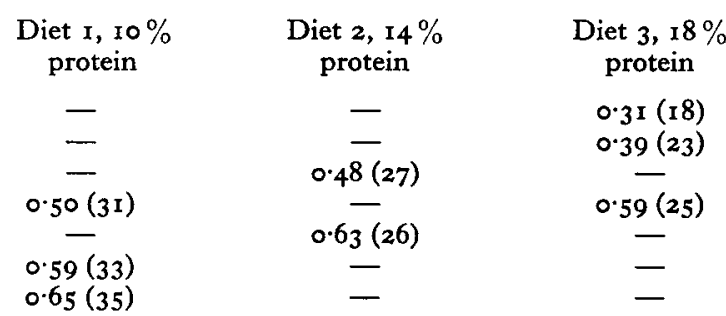

\section{Slaughter and carcass processing}

Each pig was killed by an injection of sodium pentobarbitone, $28 \mathrm{~h}$ after injection. It was suspended by the hind legs and weighed. Then the major blood vessels of the neck were cut and the carcass was bled as fully as possible. The entire alimentary tract was removed, weighed, emptied and reweighed. The alimentary tract contents were mixed and sampled; the bladder was emptied, the volume of urine was noted and a sample was retained for counting. The carcass was cut into pieces which were stored for $6 \mathrm{~d}$ at $-25^{\circ}$. Subsequently they were allowed to thaw; then they were weighed and minced. The entire mass of minced material was mixed mechanically and a primary sample of $\sim \mathrm{I} \mathrm{kg}$ was freeze-dried. The freeze-dried material was further comminuted in an electric coffee-mill before analysis.

\section{Counting procedures}

Eighty-two per cent of the disintegrations of ${ }^{42} \mathrm{~K}$ produce $\beta$ particles with a mean energy of $3.6 \mathrm{MeV}$. $\beta$ particles of this energy exhibit strongly the property of Cerenkov radiation, which is reported to be emitted when the high-energy $\beta$ particles are slowed in passing through an aqueous medium. Haberer (1965) has described the conditions required for measuring Cerenkov radiation, the primary one being that the solution is optically clear in the wavelength characteristic of the Cerenkov radiation to be measured.

This system seemed particularly suitable for measuring the ${ }^{42} \mathrm{~K}$ activity of plasma which, owing to the rapid radioactive decay of the isotope over a period of days, 
becomes so low that a high counting efficiency is required. The system was also used for urine samples, although the activity of these is usually sufficiently high for the much lower efficiency of $\gamma$-counting to be acceptable. In a series of preliminary investigations, the following procedures were developed for measuring the activity of ${ }^{42} \mathrm{~K}$ in plasma and urine by means of Cerenkov radiation.

To $5 \mathrm{ml}$ of plasma, prepared by centrifugation of $10 \mathrm{ml}$ of whole blood, were added $5 \mathrm{ml}$ of $10 \%$ trichloroacetic acid. After mixing and centrifugation, $5 \mathrm{ml}$ of the clear supernatant fraction were added to $15 \mathrm{ml}$ water in a counting vial. Urine was decolorized by shaking $30 \mathrm{ml}$ with $5 \mathrm{~g}$ of powdered charcoal, then filtering, and $10 \mathrm{ml}$ of the filtrate were added to $10 \mathrm{ml}$ of water in a counting vial. After counting, the same samples were diluted for determination of $\mathrm{K}$ as described above. All $\beta$-counting was done on a Packard Tricarb liquid scintillation spectrometer.

The activity of ${ }^{42} \mathrm{~K}$ in faeces and gut contents was at first also estimated by $\beta$-counting. For this purpose, samples were shaken with water and centrifuged. The supernatant fraction was clarified with zinc sulphate as described by Hydén (1956). Later, faeces and gut contents as well as urine were counted direct in a Packard Autogamma spectrometer.

\section{Chemical methods}

$\mathrm{K}$ was determined by flame photometry, at first with an instrument from Evans Electroselenium Ltd, Halstead, Essex, and later an instrument from Carl Zeiss, Oberkochen Wuerttemberg. Because of the mutual interference effects between $\mathrm{K}$ and sodium, three calibration curves were constructed for $\mathrm{K}$, having ratios of $\mathrm{Na}$ to $\mathrm{K}$ of $24: \mathrm{I}, 33: \mathrm{I}$ and $40: \mathrm{I}$. Both the $\mathrm{Na}$ and the $\mathrm{K}$ of the samples were measured, and, by interpolation between the three $\mathrm{K}$ calibration curves, the appropriate correction for the interference due to Na could be applied. These calibrations were used for plasma and urine samples. In analysing the ash samples of the whole carcass, one series of calibrating solutions was used, containing $\mathrm{Na}, \mathrm{Ca}$ and $\mathrm{K}$ in the ratio $0.39: 4 \cdot 22: \mathrm{I}$, these being the ratios of these elements found by Oslage (1965) in the carcasses of pigs weighing $90 \mathrm{~kg}$. The deviations from these ratios found among the pigs analysed were not sufficient to influence the magnitude of the mutual interference effects.

The contents of water, nitrogen, fat and ash in the ground carcass material were determined by conventional methods.

\section{Preliminary investigations into the method of estimating the activity of ${ }^{42} \mathrm{~K}$ in biological fuids using Cerenkov radiation}

The adequacy of the techniques of clarifying plasma and urine for counting was tested in several ways. First, $\mathrm{I} \mathrm{ml}$ of an aqueous solution containing ${ }^{42} \mathrm{~K}$ was added to vials containing either $5 \mathrm{ml}$ deproteinized plasma or $5 \mathrm{ml}$ water. The count rates for the two solutions agreed within the limits of counting error. A similar test with $10 \mathrm{ml}$ decolorized urine gave the same result. In a second test, the linearity of response to graded additions of a highly active solution of ${ }^{42} \mathrm{~K}$ to deproteinized plasma and to decolorized urine was tested. No deviations from linearity were found. Subsequent to the main part of the studies reported here, further tests (Houseman, unpublished) 
showed that the count rates obtained in plasma and urine are dependent to a small degree on the dilutions used, and a preferable procedure seems to be to deproteinize $5 \mathrm{ml}$ plasma taken before injection and include this in the standard used for counting, so that this is identical to the plasma samples counted later.

\section{Estimation of exchangeable $K$}

The estimates of total exchangeable $\mathrm{K}\left(\mathrm{K}_{\mathrm{e}}\right)$ were made from the specific activity of urine or of plasma, obtained $22-28 \mathrm{~h}$ after injection ( $24 \mathrm{~h}$ exchangeable $\mathrm{K}, \mathrm{K}_{\mathrm{e}}$ ) by the equation:

$$
\mathrm{K}_{\mathrm{e}}=\frac{I-L}{S A},
$$

where $I=$ total disintegrations $/ \mathrm{min}$ injected, $L=$ total disintegrations/min lost in urine, faeces and gut contents and $S A=$ specific activity.

From two pigs, we were unable to obtain final urine samples. For one other pig, only two urine samples were obtained which varied widely in specific activity. The following results therefore apply to seventeen of the twenty pigs.

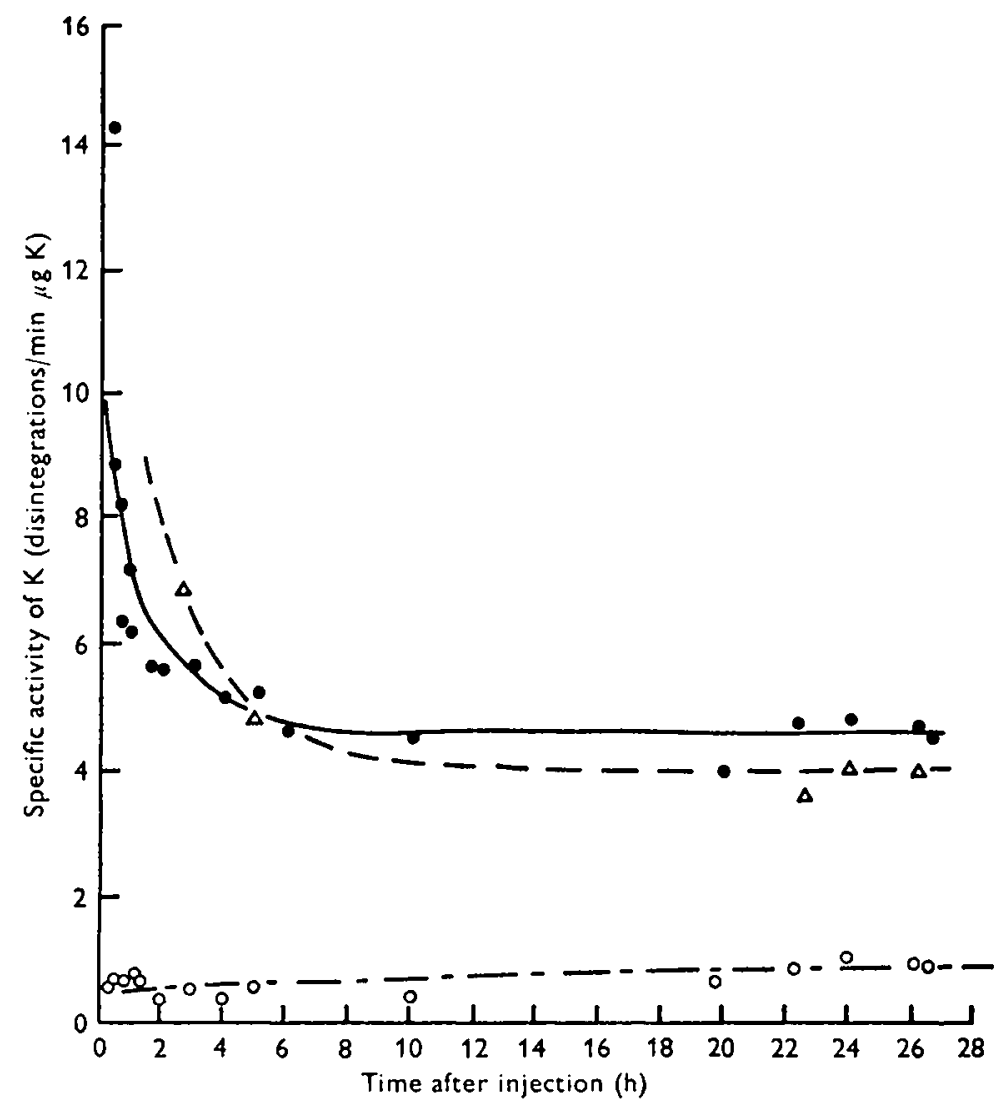

Fig. I. Time-course of specific activity of potassium in plasma, urine and erythrocytes of pigs after the intravenous injection of $\sim 400 \mu \mathrm{Ci}$ of ${ }^{42} \mathrm{~K}$. 9 , plasma; $\triangle$, urine; $\mathrm{O}$, erythrocytes. 


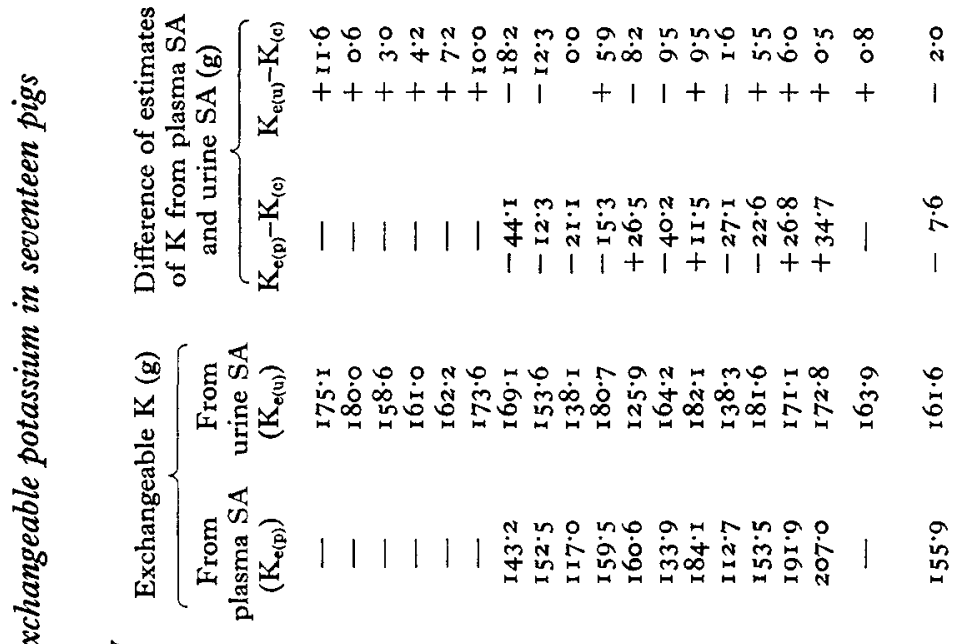

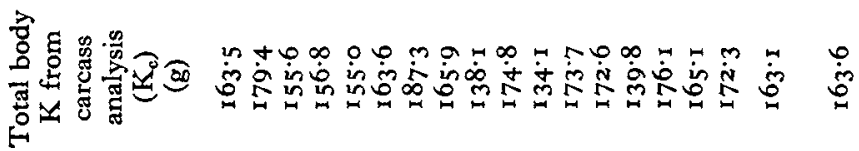

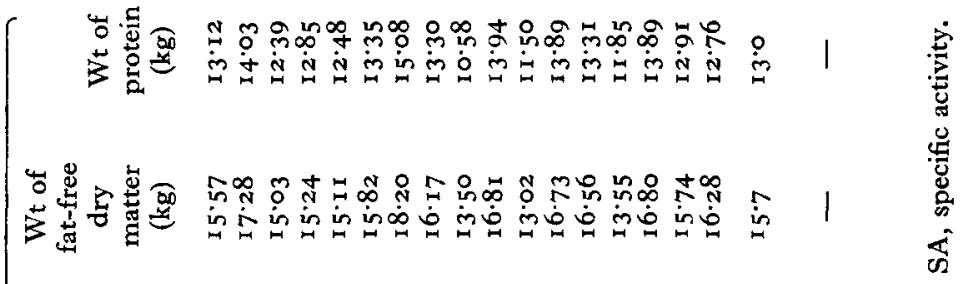

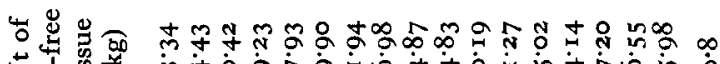

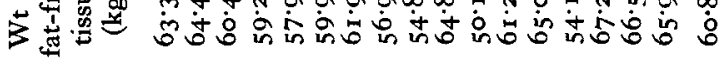

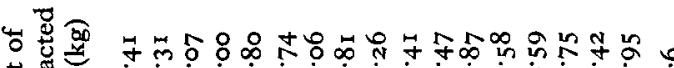

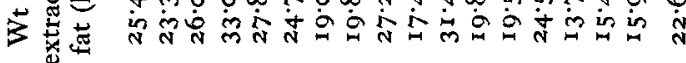

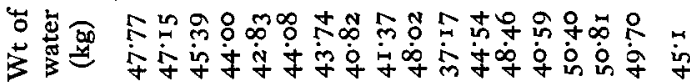

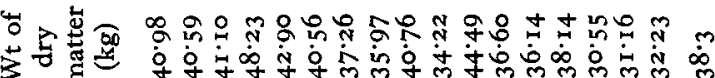

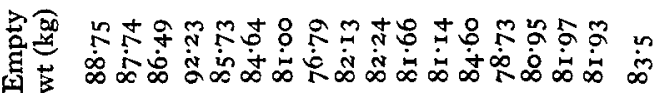




\section{RESULTS}

Loss of the label in faeces, gut contents and urine

Of the total activity injected into the pigs $0.3 \pm 0.10 \%$ was excreted in the faeces. This value includes results from nine pigs which voided no faeces during the $24 \mathrm{~h}$ after injection. The mean value for the remaining eleven pigs was $0.43 \%$. The contents of the alimentary tract contained $\mathrm{x} \cdot 5 \pm 0.28 \%$ of the injected dose. The total loss into the gut therefore amounted to $\mathrm{x} \cdot 8 \%$. The major route of isotope loss, under these conditions of starvation, was the urine, in which $3 \cdot x \pm 0.04 \%$ of the injected label was excreted.

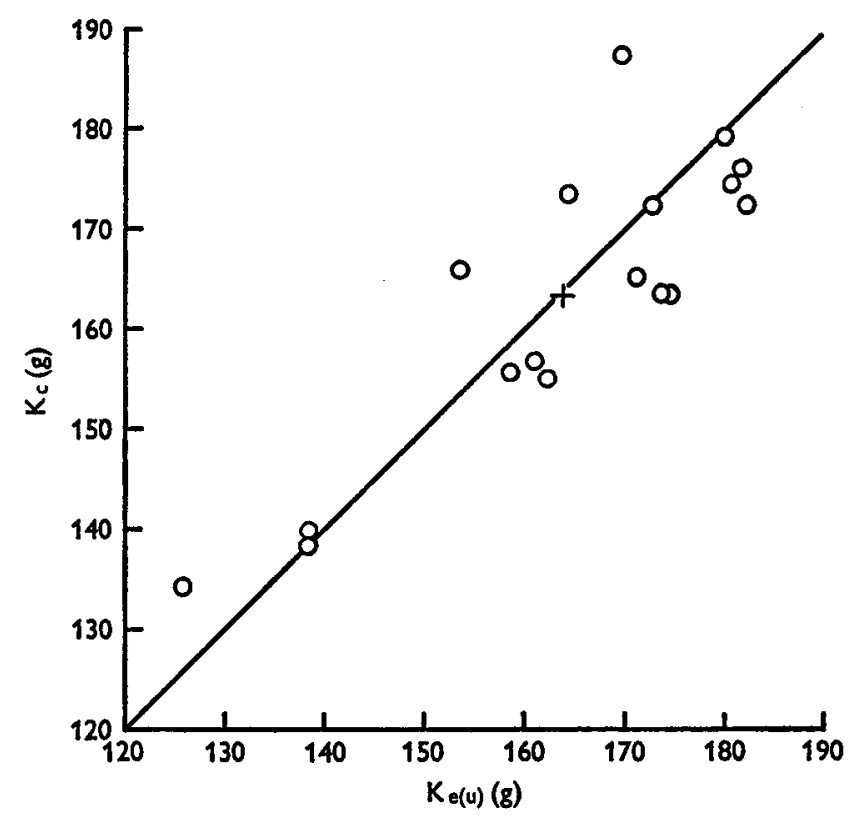

Fig. 2. Agreement between $24 \mathrm{~h}$ exchangeable potassium in pigs, calculated from the specific activity of $\mathrm{K}$ in urine $\left(\mathrm{K}_{\mathrm{e}(\mathrm{u})}\right)$ and the total $\mathrm{K}$ in the body determined by carcass analysis $\left(\mathrm{K}_{\mathrm{c}}\right)$. The line is that representing complete agreement. The cross shows the mean values of all the observations. $r=0.84$.

\section{Time-course of ${ }^{42} \mathrm{~K}$ specific activity in plasma, red cells and urine}

The specific activity of ${ }^{42} \mathrm{~K}$ in the plasma, red cells and urine of a typical animal at various times after injection is shown in Fig. I. It is clear that red cells acquire the label extremely slowly. Equilibration of the plasma is virtually complete $10-12 \mathrm{~h}$ after injection. The specific activity of urine, $24 \mathrm{~h}$ after injection, was sometimes higher and sometimes lower than that of plasma. The first sample of the day following injection was nearly always discordant with later samples.

\section{The 24 h exchangeable $K$}

Most workers have estimated exchangeable $\mathrm{K}$ from urine specific activity $\left(\mathrm{K}_{\mathbf{e}(\mathrm{u})}\right)$ and we have done this for all the pigs. In addition, for eleven pigs, we have made estimates 
of exchangeable $\mathrm{K}$ from plasma specific activity $\left(\mathrm{K}_{\mathrm{e}(p)}\right)$. The mean value of each of these two estimates is given in Table 3 , together with the mean value of total $\mathrm{K}$, determined by carcass analysis $\left(\mathrm{K}_{\mathrm{c}}\right)$. The deviations of $\mathrm{K}_{\mathrm{e}(\mathrm{u})}$ and of $\mathrm{K}_{\mathrm{e}(\mathrm{p})}$ from $\mathrm{K}_{\mathrm{c}}$ are also given in Table 3 . It is clear that $\mathrm{K}_{\mathbf{e}(\mathrm{u})}$ is the superior estimator of $\mathrm{K}_{\mathfrak{c}}$. The relation between $\mathrm{K}_{\mathrm{e}(u)}$ and $\mathrm{K}_{\mathrm{e}}$ for all seventeen pigs is shown in Fig. 2. The line shown is that of complete agreement. The mean deviation of $\mathrm{K}_{\mathrm{e}(\mathrm{u})}$ from $\mathrm{K}_{\mathrm{c}}$ is $+0.8 \mathrm{~g}$ $(+20 \mathrm{~m}$-equiv.), and the residual standard deviation from the regression $\pm 7.8 \mathrm{~g}$ (199 m-equiv.).

Table 4. Regressions of various body components of pigs on the 24 h exchangeable potassium $(g)$ predicted from urine specific activity $\left(\mathrm{K}_{\mathrm{e}(\mathrm{u})}\right)$

\begin{tabular}{|c|c|c|c|c|c|}
\hline $\begin{array}{l}\text { Dependent } \\
\text { variable }(y)\end{array}$ & Units & Regression equation & $\begin{array}{l}\text { SE of } \\
\text { regression } \\
\text { coefficient }\end{array}$ & $\begin{array}{l}\text { Residual } \\
\text { standard } \\
\text { deviation }\end{array}$ & $\begin{array}{l}\text { Correlation } \\
\text { coefficient }\end{array}$ \\
\hline Fat-free weight & $\mathrm{kg}$ & $y=16.6+0.270 K_{e(u)}$ & 0.027 & $1 \cdot 80$ & 0.93 \\
\hline Fat-free dry matter & $\mathrm{kg}$ & $y=4.27+0.0699 \mathrm{~K}_{\mathrm{e}(\mathrm{u})}$ & 0.012 & 0.79 & 0.84 \\
\hline Total protein & $\mathrm{kg}$ & $y=5.07+0.048 \mathrm{~K}_{\mathrm{e}(\mathfrak{n})}$ & 0.0108 & 0.72 & 0.76 \\
\hline Total water & $\mathrm{kg}$ & $y=12.3+0.200 K_{e(0)}$ & 0.030 & $\mathrm{I} \cdot 99$ & 0.87 \\
\hline
\end{tabular}

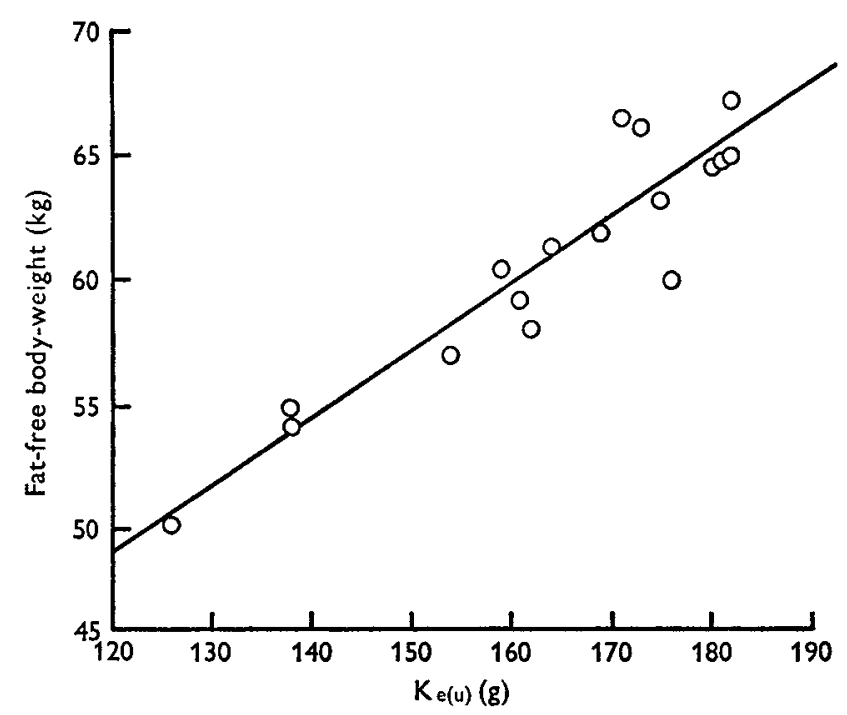

Fig. 3. Relation, in pigs, between the fat-free weight of the body and the $24 \mathrm{~h}$ exchangeable potassium calculated from urine specific activity $\left(\mathrm{K}_{\mathrm{e}(\mathrm{u})}\right) \cdot y=16 \cdot 6+0.27 \mathrm{~K}_{\mathrm{e}(\mathrm{u})} \cdot \mathrm{RSD}= \pm \mathrm{r} \cdot 8$. $r=0.93$.

\section{Relation between exchangeable $K$ and various body components}

In Table 3 are given the individual values of exchangeable $\mathrm{K}$ and of the weights of the major body components of the seventeen pigs. The regressions of the major components of the fat-free body on $\mathrm{K}_{\mathbf{e}(\mathfrak{u})}$ are given in Table 4 . The relation between $\mathrm{K}_{\mathrm{e}(\mathrm{u})}$ and fat-free body-weight is shown in Fig. 3. These results indicate that the weight of fat-free tissue can be estimated from $\mathrm{K}_{\mathrm{e}(\mathrm{u})}$ with a standard deviation of $\pm \mathrm{r} \cdot 8 \mathrm{~kg}$, which is $\pm 2 \cdot 9 \%$ of the mean. 
For the estimation of extractable body fat $(F)$ from $K_{e(u)}$, both variables were expressed per $100 \mathrm{~kg}$ of ingesta-free body-weight (EBW) to allow for the small variations in body-weight, which would tend to reduce the closeness of the inverse relation between lean tissue and fat. The regression was:

$$
\begin{aligned}
& \frac{F}{E B} \bar{W}=83.9-\frac{0.289 \mathrm{~K}_{\mathrm{e}(\mathrm{u})}}{E B W} \\
& ( \pm 0.032) \quad \mathrm{RSD}= \pm 2.5 \% \text { fat, } r=-0.92 .
\end{aligned}
$$

The relation between these variables is shown in Fig. 4 .

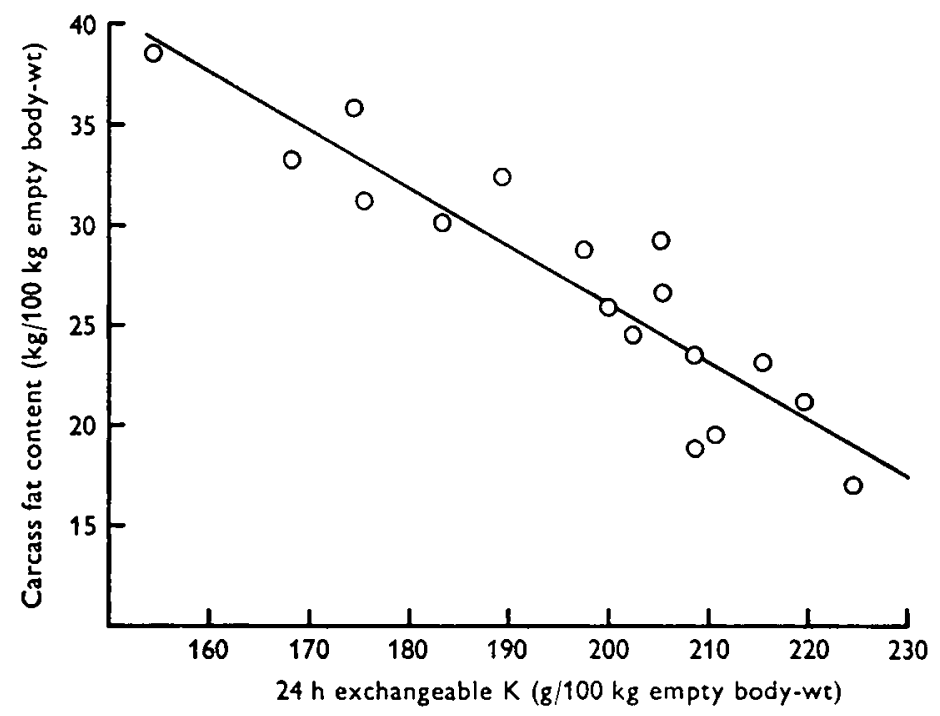

Fig. 4. Relation, in pigs, between the percentage of fat in the ingesta-free body and the $24 \mathrm{~h}$ exchangeable potassium calculated from urine specific activity expressed per $100 \mathrm{~kg}$ ingestafree body-weight, $y=83.87-0.289 x( \pm 0.032)$. RSD $= \pm 2.53 . r=-0.92$.

Table 5. Regressions of various body components of pigs on the total potassium $(\mathrm{g})$

\begin{tabular}{|c|c|c|c|c|c|}
\hline $\begin{array}{l}\text { Dependent } \\
\text { variable }\end{array}$ & Units & Regression equation & $\begin{array}{l}\text { SE of } \\
\text { regression } \\
\text { coefficient }\end{array}$ & $\begin{array}{l}\text { Residual } \\
\text { standard } \\
\text { deviation }\end{array}$ & $\begin{array}{l}\text { Correlation } \\
\text { coefficient }\end{array}$ \\
\hline $\begin{array}{l}\text { Fat-free weight } \\
\text { Fat-free dry matter } \\
\text { Total protein } \\
\text { Total water }\end{array}$ & $\begin{array}{l}\mathrm{kg} \\
\mathrm{kg} \\
\mathrm{kg} \\
\mathrm{kg}\end{array}$ & $\begin{array}{l}y=17.7+0.264 \mathrm{~K}_{\mathrm{c}} \\
y=6.5+0.092 \mathrm{~K}_{\mathrm{c}} \\
y=2.2+0.066 \mathrm{~K}_{\mathrm{c}} \\
y=17.1+0.17 \mathrm{~K}_{\mathrm{c}}\end{array}$ & $\begin{array}{l}0.047 \\
0.0023 \\
0.0065 \\
0.049\end{array}$ & $\begin{array}{l}2 \cdot 84 \\
0 \cdot 14 \\
0 \cdot 39 \\
2 \cdot 95\end{array}$ & $\begin{array}{l}0.82 \\
0.99 \\
0.94 \\
0.67\end{array}$ \\
\hline
\end{tabular}
determined by chemical analysis of the carcass $\left(\mathrm{K}_{\mathrm{c}}\right)$

Relation between chemically determined $K$ and other body components

The regression equations relating the components of the fat-free body to total $\mathrm{K}\left(\mathrm{K}_{\mathrm{e}}\right)$ are given in Table 5. The equations are similar to those for $\mathrm{K}_{\mathbf{e}(\mathrm{u})}$. It is evident, however, that $\mathrm{K}_{\mathbf{e}(\mathrm{u})}$ predicts fat-free body-weight and total water more closely than does $K_{c}$, and $K_{c}$ predicts fat-free dry matter more closely than does $K_{e(u)}$. The relation between fat/roo $\mathrm{g}$ empty body-weight and $\mathrm{K}_{\mathrm{c}}$ was also numerically similar to that with $K_{e(u)}$, but the RSD was $\pm 3.3 \%$ fat, and the correlation coefficient -0.85 . 


\section{DISCUSSION}

The main purpose of this experiment was to evaluate a ${ }^{42} \mathrm{~K}$ dilution method as a technique in animal production research. In this context, the most important measure of body composition is probably the fat-free weight, as this is closely related to the lean meat content of the carcass. The linear equation predicting fat-free weight from exchangeable $\mathrm{K}$ estimated by our method gave a residual standard deviation of $\pm \mathrm{r} .8 \mathrm{~kg}$ for fat-free weight, and this figure is probably the best index of the precision of the method.

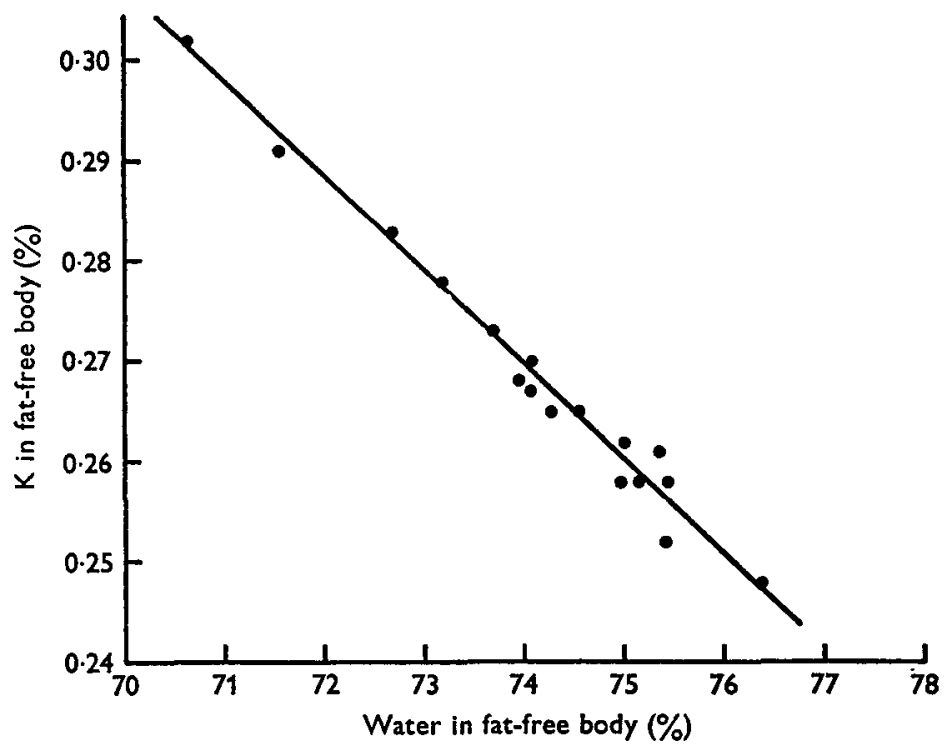

Fig. 5. Relation, in pigs, between the percentages of potassium and of water in the fat-free and ingesta-free body. $y=0.965-0.0094 x . r=-0.99$.

The choice of whether to base the estimates of exchangeable $\mathrm{K}$ on urine or plasma specific activity was resolved for us by the evidently superior agreement of the former with carcass $\mathrm{K}$ determined chemically. This was in spite of the much better repeatability of plasma equilibrium specific activity from hour to hour. Flear, Cooke, Sivyer \& Domenet ( 1963 ) similarly reported that successive estimates of specific activity of urine made $24 \mathrm{~h}$ after injection varied considerably in certain human subjects, but less in others, and were not able to trace the origin of this variable response, or to foretell in which patients ${ }^{42} \mathrm{~K}$ would be unusually slow to equilibrate. They concluded that equilibration is achieved at different times in different subjects and that this fact must be allowed for in using the method. Our experience makes us share this view, and we would recommend that as many successive estimates as possible be made, between 20 and $30 \mathrm{~h}$ after injection, of urine specific activity, in order to establish for each animal the time when equilibrium is reached. This empirical method seems to us more likely to yield correct values than any approach which treats all animals identically.

The difference between the specific activity of urine and plasma was surprising, 
particularly in view of the greater stability of plasma specific activity. Corsa $e t$ al. (1950) compared the specific activities of plasma and urine in four patients and found that they agreed 'within the accuracy of plasma readings'. This is not our experience for, whereas we have made highly repeatable estimates of plasma specific activity, the urine specific activity, estimated at the same time, was considerably different, sometimes higher and sometimes lower. It is clearly desirable that in future work these relationships should be examined more closely.

Table 6. Estimates, from the the present work and from the literature, of the proportion of $K$ in the fat-free body $(F F W)$ and of the ratio $K: N$ in the bodies of pigs of $90 \mathrm{~kg}$ live weight

\begin{tabular}{|c|c|c|c|}
\hline Source of values & $\begin{array}{c}\text { K/FFW } \\
(\mathrm{g} / \mathrm{kg})\end{array}$ & $\begin{array}{l}\mathrm{K}: \mathrm{N} \\
(\mathrm{mg} / \mathrm{g})\end{array}$ & $n$ \\
\hline $\begin{array}{l}\text { Oslage (1965) } \\
\text { Pfau (1966) }\end{array}$ & $\begin{array}{l}2 \cdot 58 \\
2 \cdot 77\end{array}$ & $\begin{array}{l}76 \cdot \mathrm{r} \\
78 \cdot 6\end{array}$ & $\begin{array}{l}6 \\
4\end{array}$ \\
\hline Stant, Martin \& Kessler (I969) * & $\left\{\begin{array}{l}2 \cdot 7 x \\
2 \cdot 64\end{array}\right.$ & $\begin{array}{l}80 \cdot 2 \\
78 \cdot 7\end{array}$ & 5 \\
\hline $\begin{array}{l}\text { Weighted mean of above results } \\
\text { Present results }\end{array}$ & $\begin{array}{l}2.67 \\
2.68\end{array}$ & $\begin{array}{l}78 \cdot 4 \\
78 \cdot 5\end{array}$ & 20 \\
\hline
\end{tabular}

Turning to the relation between $\mathrm{K}$ content and body composition, it is clear that the $\mathrm{K}$ determined chemically $\left(\mathrm{K}_{\mathrm{c}}\right)$ forms a very constant fraction of the fat-free dry matter, with a mean concentration of $\mathrm{I} \cdot 04 \pm 0.010 \%(26.6 \pm 0.25 \mathrm{~m}$-equiv./100 g).

The mean concentration of $K$ in the fat-free body, and the mean ratio of $K: N$, were in close agreement with values in the literature, given in Table 6.

Exchangeable $\mathrm{K}$, as is to be expected, was less closely related than $\mathrm{K}_{\mathrm{c}}$ to the fatfree dry matter. On the other hand, $K_{c}$ was less closely related than $K_{e(u)}$ to fat-free weight. It may be that the $\mathrm{K}$ associated with the body water is more readily exchangeable than that in tissues containing little water.

As a corollary of this, it is interesting that there was a close relationship between the percentage $\mathrm{K}$ (determined chemically) in the fat-free body and the water content of the fat-free body. This relationship is shown in Fig. 5. It seems therefore, from this study, that neither the $\mathrm{K}$ nor the water content of the fat-free body can be regarded as a constant, as is often assumed, but that each varies with the other. Neither, however, was closely related to age, fat-free weight, percentage fat or diet, the factors one would think most likely to be associated with such variation.

Thanks are due to the Meat and Livestock Commission for a research scholarship to one of us (RAH) and to Mr Ian Phillip for care of the animals. 


\section{REFERENCES}

Agricultural Research Council (1967). The Nutrient Requirements of Farm Livestock. No. 3. Pigs. London: Agricultural Research Council.

Anderson, D. M. \& Elsley, F. W. H. (1969). F. agric. Sci., Camb. 72, 475.

Corsa, L. Jr, Olney, J. M. Jr, Steenburg, R. W., Ball, M. R. \& Moore, F. D. (1950). F. clin. Invest. 29, 1280.

Flear, C. T. G., Cooke, W. T., Sivyer, A. \& Domenet, J. (1963). Clinica chim. Acta 8, 768.

Fuller, M. F., Houseman, R. A. \& Cadenhead, A. (1970). Proc. Nutr. Soc. 29, 35 A.

Haberer, K. (1965). Atom Wirtsch. 1o, 36.

Hydén, E. S. (1956). K. LantbrHögsk. Annlr 22, 139.

Kirton, A. H. \& Pearson, A. M. (1963). Ann. N.Y. Acad. Sci. 110, 22 1.

Moore, F. D. (1946). Science, N.Y. 104, 157.

Oslage, H. J. (1965). LandbForsch-Volkenrode 15, 107.

Pfau, A. (1966). Landw. Forsch. Sonderheft no. 20, p. I 39.

Stant, E. G. Jr, Martin, T. G. \& Kessler, W. V. (1969). F. Anim. Sci. 29, 547.

Talso, P. J., Miller, C. E., Carballo, A. J. \& Vasquez, I. (I960). Metabolism 9, 456. 